\title{
Plastic film mulching with ridge planting alters soil chemical and biological properties to increase potato yields in semiarid Northwest China
}

Mingfu Shi ${ }^{1}$, Yichen Kang ${ }^{1}$, Weina Zhang ${ }^{1}$, Xinyu Yang ${ }^{1}$, Yanling Fan ${ }^{1}$, Huifang Yu ${ }^{1}$, Ruyan Zhang ${ }^{1}$, Aixia Guo ${ }^{2}$ and Shuhao Qin ${ }^{1 *}$ (D)

\begin{abstract}
Background: The growth of potato (Solanum tuberosum L.) is severely affected by the complex and variable soil environment, and film mulching has been widely used for potato growth in semiarid areas of western China. However, there are few studies on the effects of film mulching on soil quality and tuber yield in potato fields.

Methods: The effects of four mulching patterns (flat plot without film mulching, FP; flat plot with film mulching, FPM; ridge planting with half mulch, RPHM; ridge planting with full mulch, RPFM) on soil chemical and biological properties and potato tuber yield were investigated during two growing seasons (2018 and 2019) in the field.

Results: The results showed that compared with FP, the mulching treatments significantly increased the tuber yield of potato, with an increase of $3.7-20.77 \%$ and $7.89-26.35 \%$ in 2018 and 2019 , respectively, and the yield of RPFM was higher than that of other treatments. In both growing seasons, RPFM significantly increased the contents of alkalihydrolyzed $\mathrm{N}$ and available $\mathrm{P}$, and the activities of soil urease, catalase, alkaline phosphatase, and sucrase. Bacterial and actinomycete counts were significantly higher in RPFM than those in the other treatments. Furthermore, RPFM significantly increased large potatoes and decreased small potatoes. Pearson's correlation analysis revealed that soil alkaline dissolved nitrogen and actinomycete populations were the main factors affecting potato yield formation.
\end{abstract}

Conclusions: These results indicate that RPFM can improve the soil environment and further increase potato tuber yield, which is a viable option for potato production in semiarid areas.

Keywords: Plastic film mulching, Soil index, Soil microorganism, Potato production

\footnotetext{
*Correspondence: qinsh@gsau.edu.cn

${ }^{1}$ College of Horticulture, Gansu Agricultural University, Lanzhou 730070,

China

Full list of author information is available at the end of the article
} 


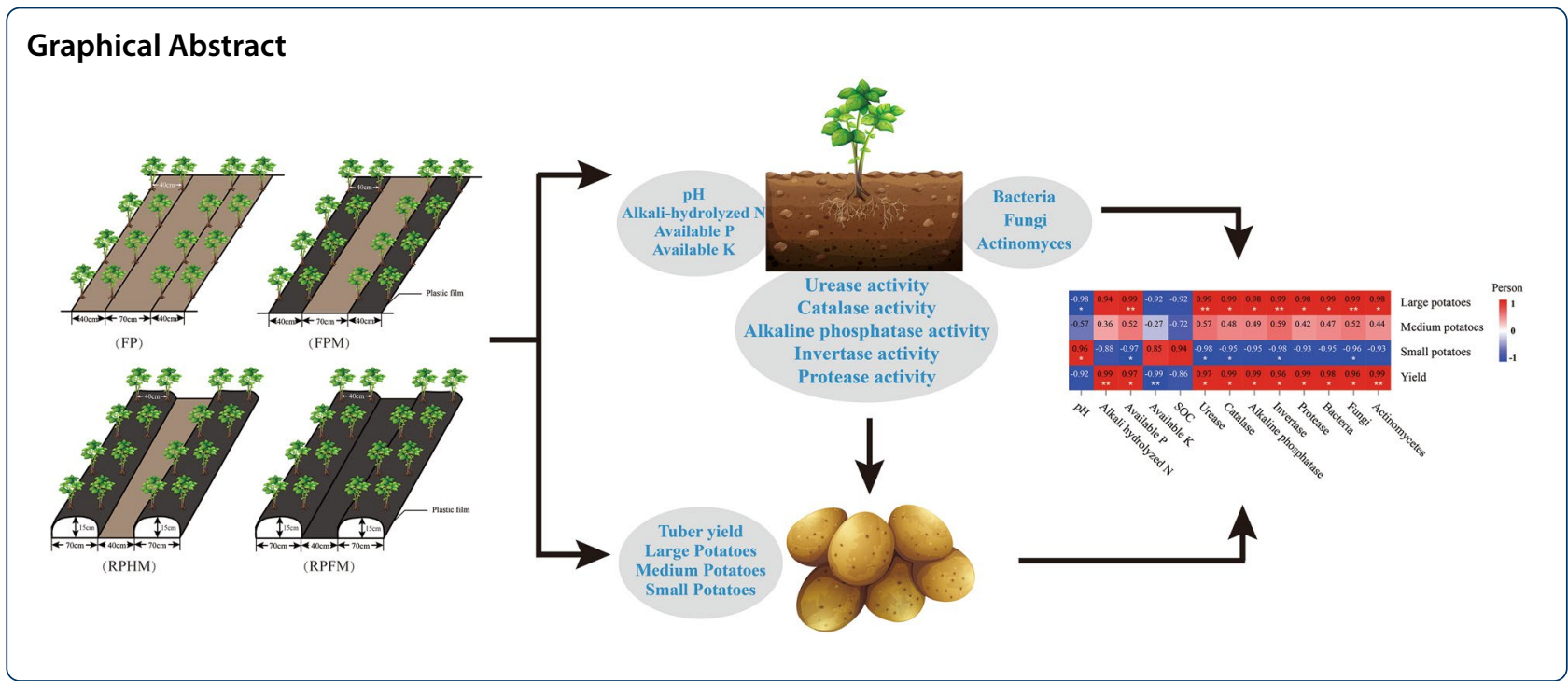

\section{Background}

Potato (Solanum tuberosum L.) is an important food crop in the semiarid area of the western Loess Plateau, accounting for $36 \%$ of the total potato area in China [1, 2]. Compared to other crops in the region, the potato has a higher yield and better economic benefits [3-5]. In recent years, the planting area of potatoes in this area is expanding, and the planting years are also extending. However, potato growth in the region is limited by environmental factors, because the potato is grown mainly in the semiarid area, which has inadequate rainfall and poor soils [6]. Therefore, climatic characteristics and potato planting status in the semiarid area of central Gansu require the application of reasonable farming measures to improve soil structure and the use of limited natural precipitation to increase crop yield.

Tuber yield is closely related to soil quality, which is determined by a variety of factors including soil physical and chemical properties, enzyme activity, and microbial abundance [7-9]. However, with the single farming method, such as continuous planting, soil structure is destroyed, physical and chemical properties deteriorate, and storage capacity becomes poor, which in turn affects plant growth and development, leading to crop yield reduction [9-12]. As a result, new agricultural practices are urgently needed to address the worsening of soil quality and yield reduction.

Soil mulching is a widely used method in crop cultivation and offers many advantages [13]. For example, mulching improves soil moisture retention, facilitates early crop growth and development, changes soil physical and chemical properties, and reduces weeds, all of which contribute to higher crop yields [14-18]. Plastic film mulch is a common soil mulch, which is widely used in arid and semiarid areas of China and has become an important technology in agricultural production [2, $16,17]$. Mulching can significantly improve soil structure, increase soil water retention capacity, and promote crop growth and yield [2, 13, 15]. Zhou et al. [19] showed that plastic film mulching significantly increased both the aboveground and belowground biomass of maize. Furrow-ridge mulching and tillage improve the microecological environment of crop rhizospheres and have effects on the soil microbial community structure that are significantly different from those of traditional planting methods [13]. The thermal effect of plastic film mulching indirectly promoted the use of water by plants, resulting in a significant alternation of soil dryness and wetness [15]. Such changes provided favorable conditions for crop growth and development [17, 20].

The benefits of plastic mulch have been used only for limited soil properties such as temperature and moisture [21-23]. However, few studies have investigated more detailed soil properties and plant parameters, especially in the semiarid agricultural zone of central Gansu Province, China. Therefore, there is an urgent need to focus on more detailed soil properties and plant parameters such as $\mathrm{pH}$, nutrients, enzyme activity, microorganisms, and yield after mulching. It can be used as a basis for evaluating the combined effects of plastic film mulching and revealing the relationship between soil properties and potato yield in semiarid areas.

This study focuses on the effects of plastic film mulching on soil chemical properties, enzyme activities, microbial abundances, and potato yields for 2 years in the semiarid area of central Gansu Province. The goal was to select suitable tillage and mulching patterns that improved soil quality and increased potato yield. The 
results will provide technical reference to improve soil quality and obtain high potato yields in semiarid areas.

\section{Materials and methods}

\section{Experimental site}

The research was conducted from April to September in 2018 and 2019 at the Dingxi Experimental Station (35 $\left.33^{\prime} \mathrm{N}, 104^{\circ} 35^{\prime} \mathrm{E}\right)$ of the Institute of Agricultural Sciences in Gansu Province, Northwest China. The site altitude is $1300 \mathrm{~m}$. Long-term annual precipitation at the site averages $390 \mathrm{~mm}$ year $^{-1}$, occurring primarily from June to September. The annual average evaporation capacity is $1531 \mathrm{~mm}$ year ${ }^{-1}$, and the annual average temperature is $6.4{ }^{\circ} \mathrm{C}$. The monthly average rainfall and temperature during the growing season in 2018 and 2019 are shown in Fig. 1. The potato variety used in the experiment was 'Xindaping', whereas the previous crop was corn. The test site had Calcaric Cambisols, which was typical of the Loess Plateau [24]. At the beginning of the experiment, chemical properties of the 0 to $-20 \mathrm{~cm}$ soil layer were as follow: $\mathrm{pH}, 8.20$; alkali-hydrolyzed nitrogen $(\mathrm{N})$, $30.3 \mathrm{mg} \mathrm{N} \mathrm{kg}^{-1}$; available phosphorus (P), $39.7 \mathrm{mg} \mathrm{P} \mathrm{kg}^{-1}$; available potassium (K), $255 \mathrm{mg} \mathrm{K} \mathrm{kg}^{-1}$; and soil organic carbon (SOC), $17.6 \mathrm{~g} \mathrm{C} \mathrm{kg}^{-1}$.

\section{Experimental design}

The experimental design included four treatments: flat plot without film mulching (FP), flat plot with film mulching (FPM), ridge planting with half mulch (RPHM), and ridge planting with full mulch (RPFM). The experiment was a randomized block design with three replications per treatment for 12 plots, each plot was 55 square meters. Potatoes were planted in 2018 and 2019 with $40 \mathrm{~cm}$ in-row spacing and $35-\mathrm{cm}$ plant spacing at a planting density of 53,775 plants ha ${ }^{-1}$ (Fig. 2). Before plastic film mulching, $\mathrm{N}, \mathrm{P}$, and $\mathrm{K}$ fertilizers were applied at 45.0, 12.0 , and $60.0 \mathrm{~kg} \mathrm{ha}^{-1}$, respectively. Nitrogen fertilizer, phosphorus fertilizer, and potassium fertilizer were urea ( $\mathrm{N} 46 \%)$, superphosphate $\left(\mathrm{P}_{2} \mathrm{O}_{5} 14 \%\right)$, and potassium sulfate $\left(\mathrm{K}_{2} \mathrm{O} 60 \%\right)$. All fertilizers were applied at one time. Then the plastic mulch, a 0.02 -mm-thick black polyethylene film, was laid by manual method. Tubers were sown on April 12 (2018) and April 15 (2019) and harvested in both years on September 6. In both growing seasons, potatoes received only natural precipitation. Other management procedures followed standard agricultural practices, including weeding every 7 days and spraying pesticides every month to control pests and diseases.

\section{Collection of soil samples for analysis}

Soil samples $(0-20 \mathrm{~cm})$ were collected before sowing, and then, the soil samples $(0-20 \mathrm{~cm})$ around potato roots were collected on June 18, July 23, and August 21 in both years. Soil samples were collected at five points in each plot and then fully mixed into a composite sample. Samples were stored at $-80^{\circ} \mathrm{C}$ until laboratory analyses.

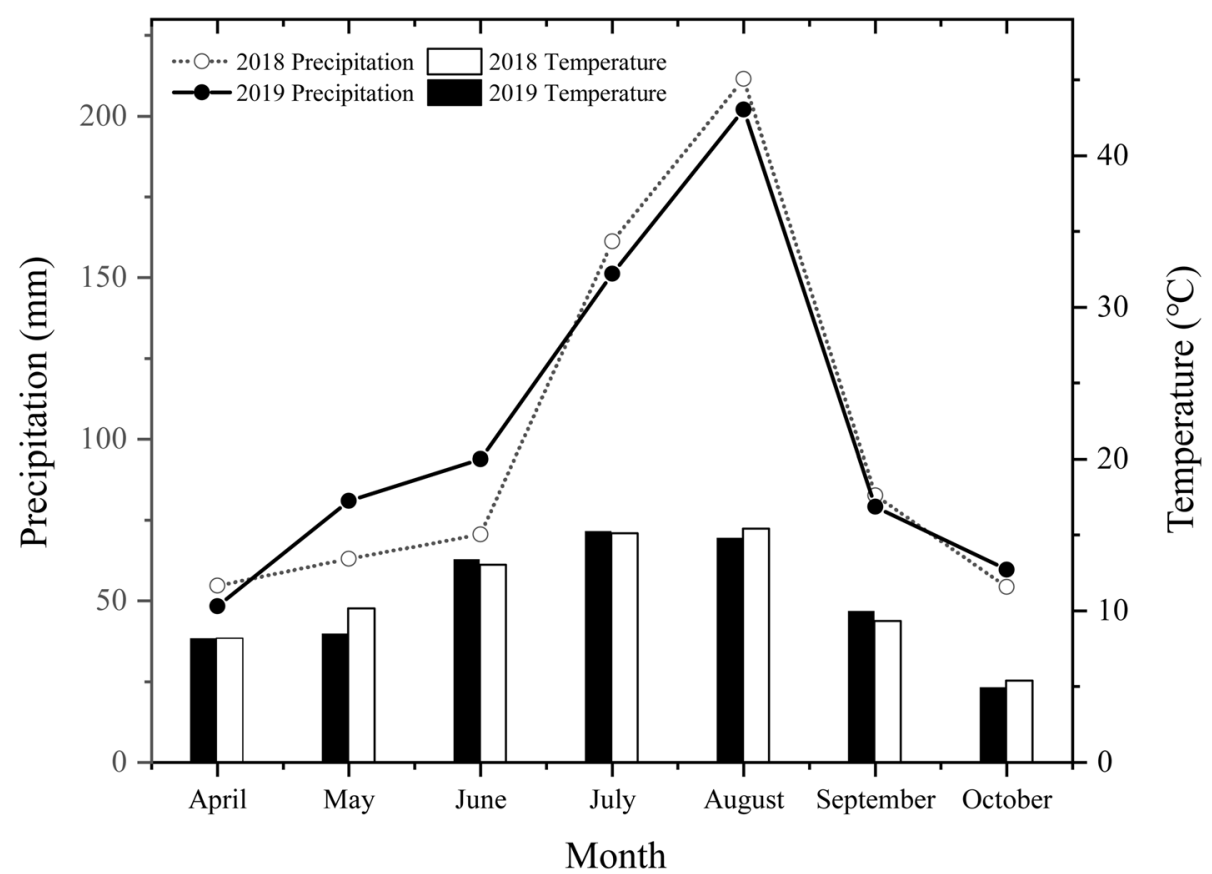

Fig. 1 Monthly average rainfall $(\mathrm{mm})$ and average temperature $\left({ }^{\circ} \mathrm{C}\right)$ in the potato growing season in 2018 and 2019 in Gansu Province, Northwest China 


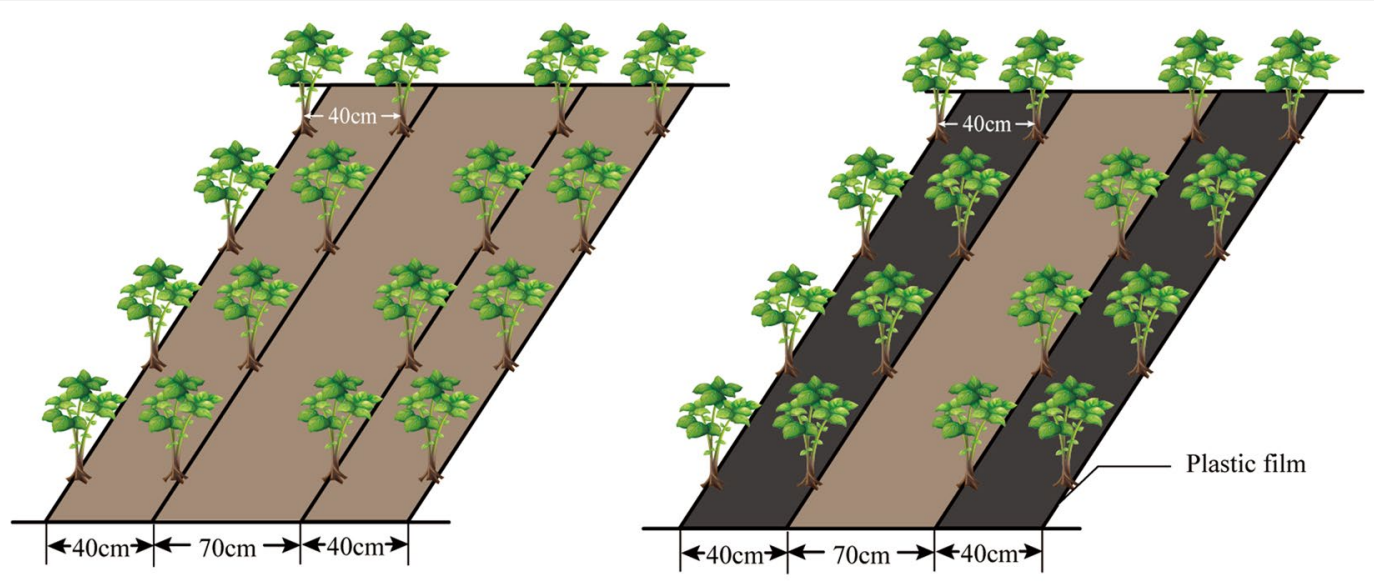

(a)

(b)

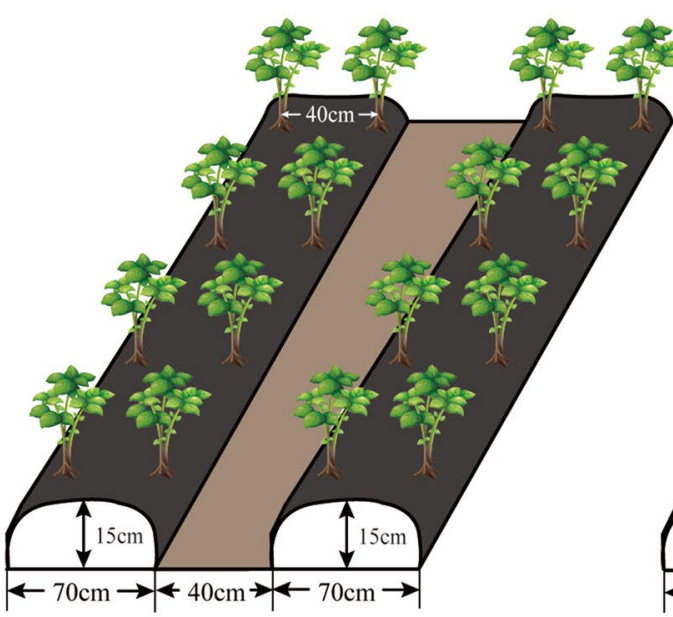

(c)

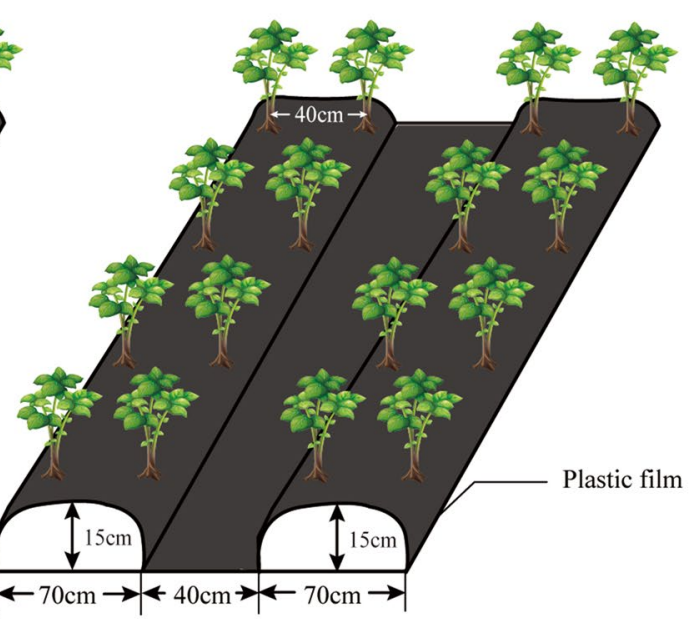

(d)

Fig. 2 Diagrams of four plastic film treatments used in a potato field. a Flat plot without film mulching; $\mathbf{b}$ flat plot with film mulching; $\mathbf{c}$ ridge planting with half mulch; $\mathbf{d}$ ridge planting with full mulch

\section{Soil physical properties}

Alkali-hydrolyzed $\mathrm{N}$ was determined by the alkaline hydrolysis diffusion method [25]. First, diffusion absorption by alkaline digestion distillation was used, and then, alkali-hydrolyzed $\mathrm{N}$ was detected by titration with boric acid. Soil available $\mathrm{P}$ was determined by the molybdenum-antimony anti-colorimetric method [25]. Soils were leached with $0.5 \mathrm{~mol} \mathrm{~L}^{-1} \mathrm{NaHCO}_{3}$; molybdenum-antimony anti-reagent was added for color development; and then, $\mathrm{P}$ was detected at $880 \mathrm{~nm}$ using a spectrophotometer. Soil available $\mathrm{K}$ was determined by a flame photometric method [26]. SOC was determined by the dichromate oxidation method [27]. Soils were leached with $1.0 \mathrm{~mol} \mathrm{~L}^{-1} \mathrm{NH}_{4} \mathrm{OAc}$, and $\mathrm{K}$ was detected by flame photometer. A pH meter (PHS-3E, Precision Scientific Instrument Co., Ltd., Shanghai, China) measured $\mathrm{pH}$ in a 1:5 soil:water ratio.

\section{Soil enzyme activities}

Urease and catalase activities were determined by the sodium hypochlorite-phenol colorimetric method and potassium permanganate $\left(\mathrm{KMnO}_{4}\right)$ titration, respectively [28]. To determine urease activity, urea was the substrate, and results were expressed as the amount of $\mathrm{NH}_{3}-\mathrm{N}$ released from the enzymatic digestion of urea incubated at $37{ }^{\circ} \mathrm{C}$ for $24 \mathrm{~h}$. Activities of soil alkaline phosphatase and sucrase were determined by methods similar to those of Kucharski et al. [29]. Alkaline phosphatase activity was determined by the sodium benzene phosphate colorimetric method. Sucrase activity was determined by the 3,5-dinitrosalicylic acid colorimetric method using sucrose as the substrate, and results were expressed as the amount of glucose measured after $24 \mathrm{~h}$ of incubation at $37^{\circ} \mathrm{C}$. Protease activity was determined by the ninhydrin colorimetric method [30]. 


\section{Soil microorganism abundance}

Numbers of bacteria, fungi, and actinomycetes were determined according to procedures described by Kucharski et al. [29]. Different microbial groups were analyzed using selective plating at three different times in a growing season. Beef paste peptone agar medium was used for bacteria, Martin-Bengal red medium was used for fungi, and modified Gaoshi No. 1 medium was used for actinomycetes, provided by Beijing Solarbio Science Technology Co., Ltd (Beijing, China).

\section{Yield and yield characters}

Tuber yield was determined from five plants randomly selected in each plot, and then, yield per hectare was calculated. Potatoes were separated into large $(>250 \mathrm{~g})$, medium (50 to $250 \mathrm{~g})$, and small $(<50 \mathrm{~g})$ tubers.

\section{Statistical analyses}

Two-way analysis of variance (ANOVA) was used to analyze the effects of the month, treatment, and month $\times$ treatment on soil chemical properties, soil enzyme activity, and soil microbial population. Meanwhile, the effects of year, treatment, and year $\times$ treatment on tuber yield and yield components were analyzed using two-way ANOVA. Significant differences $(P<0.05)$ were analyzed by Duncan's method of multiple comparisons. One-way ANOVA and Duncan's multiple extreme difference test $(P<0.05)$ were used to assess separate effects of month and treatment on soil chemical properties, soil enzyme activity and soil microbial population, and year and treatment on tuber yield and yield components. Data were expressed as mean \pm standard error. The relationship between each index was evaluated by Pearson correlation analysis. SPSS 19.0 (IBM 2010, Armonk, USA) was used for statistical analysis. Origin 9.0 (origin lab Corporation, Northampton, USA.) was used to prepare graphics.

\section{Results}

\section{Soil chemical properties}

Month and treatment had significant effects on soil $\mathrm{pH}$, alkali-hydrolyzed $\mathrm{N}$, available $\mathrm{P}$, and available $\mathrm{K}$ both in 2018 and 2019. Month $\times$ treatment had a significant effect on $\mathrm{pH}$, alkali-hydrolyzed $\mathrm{N}$, and available $\mathrm{P}$. In 2019 , month $\times$ treatment had a significant effect on $\mathrm{pH}$ and available $\mathrm{K}(P<0.05)$ (Additional file 1: Table S1). Soil chemical properties were significantly different among treatments, except for SOC (Fig. 3a-e). Specifically, regardless of year or sample date, RPFM had the highest contents of soil alkali-hydrolyzed $\mathrm{N}$ and available $\mathrm{P}$ (Fig. 3b, c). However, compared with RPFM, FP significantly increased soil $\mathrm{pH}$ and available $\mathrm{K}$ content (Fig. 3a, d). Notably, soil alkali-hydrolyzed $\mathrm{N}$ and available $\mathrm{P}$ contents were significantly different between RPFM and FP on all sample dates. However, there was no significant difference in SOC between treatments (Fig. 3e).

Within the growing season, soil $\mathrm{pH}$ and contents of alkali-hydrolyzed $\mathrm{N}$, available $\mathrm{P}$, and available $\mathrm{K}$ in all treatments were higher in 2019 than in 2018. From June to August in 2019, the contents of alkali-hydrolyzable $\mathrm{N}$, available $\mathrm{P}$, and available $\mathrm{K}$ increased by $17.9-38.3 \%$, $42.0-53.0 \%$, and $0.6-5.6 \%$ compared with those in 2018 , respectively. Nevertheless, soil $\mathrm{pH}$, alkali-hydrolyzed $\mathrm{N}$, available $\mathrm{P}$, and available $\mathrm{K}$ in each treatment decreased from June to August in both years.

\section{Soil enzymatic activity}

The month and treatment had significant effects on soil urease activity, catalase activity, alkaline phosphatase activity, invertase activity, and protease activity, except for the month of 2019, which had no significant effect on protease activity. Month $\times$ treatment had no significant effect on soil enzyme activity (Additional file 1: Table S1). The effects of different film mulching treatments on soil enzyme activities are shown in Fig. 4a-d. In both 2018 and 2019, activities of urease, catalase, alkaline phosphatase, and sucrase were significantly higher in RPFM than in FP, but the difference in protease activity was not significant. Compared with 2018, in 2019, urease activity increased by $29.3 \%$ to $41.8 \%$, catalase activity by $16.9 \%$ to $22.8 \%$, alkaline phosphatase activity by $27.6 \%$ to $33.0 \%$, sucrase activity by $5.6 \%$ to $5.9 \%$, and protease activity by $3.8 \%$ to $8.7 \%$.

\section{Bacteria, fungi, and actinomycetes}

Month and treatment had significant effects on soil bacteria, fungi, and actinomyces. Meanwhile, month $\times$ treatment had a significant effect on Actinomyces (Additional file 1: Table S1). Plastic film mulching significantly affected numbers of bacteria (Fig. 5a), fungi (Fig. 5b), and actinomycetes (Fig. 5c). In addition, the number of bacteria and actinomycetes increased during the growing season (Fig. 5a, c). During the growing season (June to August) in both years, numbers of bacteria, fungi, and actinomycetes increased significantly with mulching compared with FP. In 2018, the number of bacteria increased by $72.2-97.2 \%$, fungi by $73.3-86.3 \%$, and actinomycetes by $84.7-125.0 \%$ under the mulch treatment. Notably, numbers of bacteria and actinomycetes increased by $41.7-44.0 \%$ and $31.3-108.7 \%$, respectively, in 2019 compared with 2018, but numbers of fungi decreased by $13.6 \%$ to $-18.3 \%$.

\section{Yield and yield components}

The analysis in Additional file 1: Table S2 showed that year had a significant effect on large potatoes, medium 


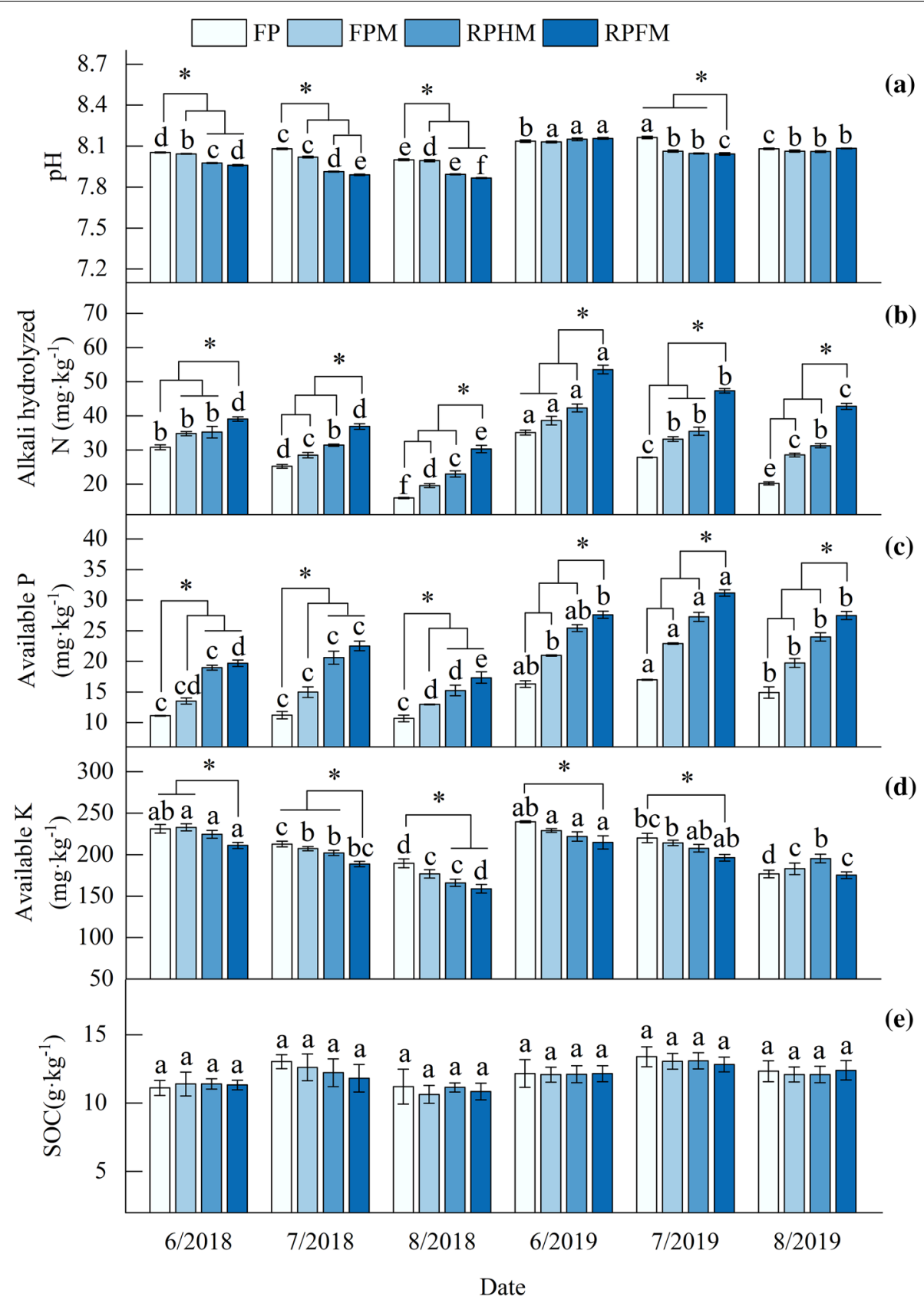

Fig. 3 Effects of plastic film mulching treatments for potato on a soil pH; b alkali-hydrolyzed nitrogen; c available phosphorus; $\mathbf{d}$ available potassium and $\mathbf{e}$ SOC. Different lowercase letters indicate significant differences for the same treatment on different sample dates $(P<0.05)$, and asterisks indicate significant differences among treatments on the same sample date $(P<0.05)$. FP, flat plot without film mulching; FPM, flat plot with film mulching; RPHM, ridge planting with half mulch; RPFM, ridge planting with full mulch

potatoes, and tuber yield, while treatment had a significant effect on large potatoes, medium potatoes, small potatoes, and tuber yield, and year $\times$ treatment had a significant effect only on large potatoes and small potatoes. In both years, yield was in the order RPFM $>$ RPHM $>$ FPM $>$ FP (Fig. 6). The yield of mulching treatments (RPFM, RPHM, and FPM) was significantly higher than that of FP by $3.7-20.8 \%$ in 2018 and by $7.9-26.4 \%$ in 2019 . Compared with 2018 , tuber yield increased by $7.0 \%$ to $11.9 \%$ in 2019 . In both years, the percentage of large potatoes was significantly 


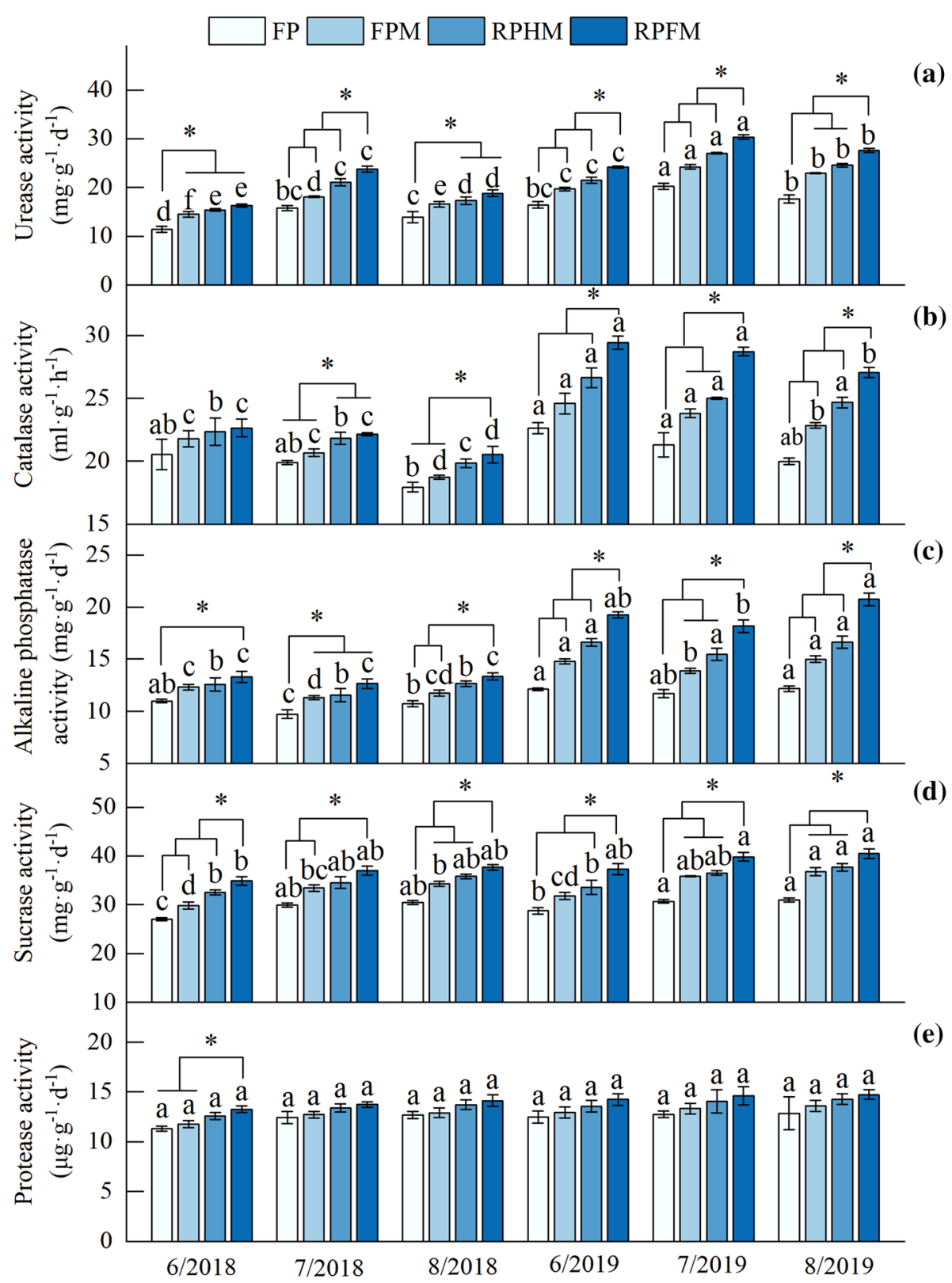

Fig. 4 Effects of plastic film mulching treatments for potato on a urease activity, $\mathbf{b}$ catalase activity, $\mathbf{c}$ alkaline phosphatase activity, $\mathbf{d}$ sucrase activity, and e protease activity. Different lowercase letters indicate significant differences for the same treatment on different sample dates $(P<0.05)$, and asterisks indicate significant differences among treatments on the same sample date $(P<0.05)$. FP, flat plot without film mulching; FPM, flat plot with film mulching; RPHM, ridge planting with half mulch; RPFM, ridge planting with full mulch

higher in RPFM, RPHM, and FPM than in FP (Table 1). By contrast, in FP, the percentage of small potatoes was significantly higher than that in mulching treatments (Table 1). The percentage of large potatoes in each treatment was higher in 2019 than in 2018, increasing by $3.7 \%$ to $10.8 \%$, whereas the percentage of small potatoes was lower.

\section{Pearson correlation analysis}

Pearson coefficients of correlation were used to measure the correlation between two different indicators (Fig. 7). Available P content, urease, catalase, alkaline phosphatase, sucrase, and protease activities, and bacterial and fungal numbers were significantly positively correlated with yield, whereas the content of 


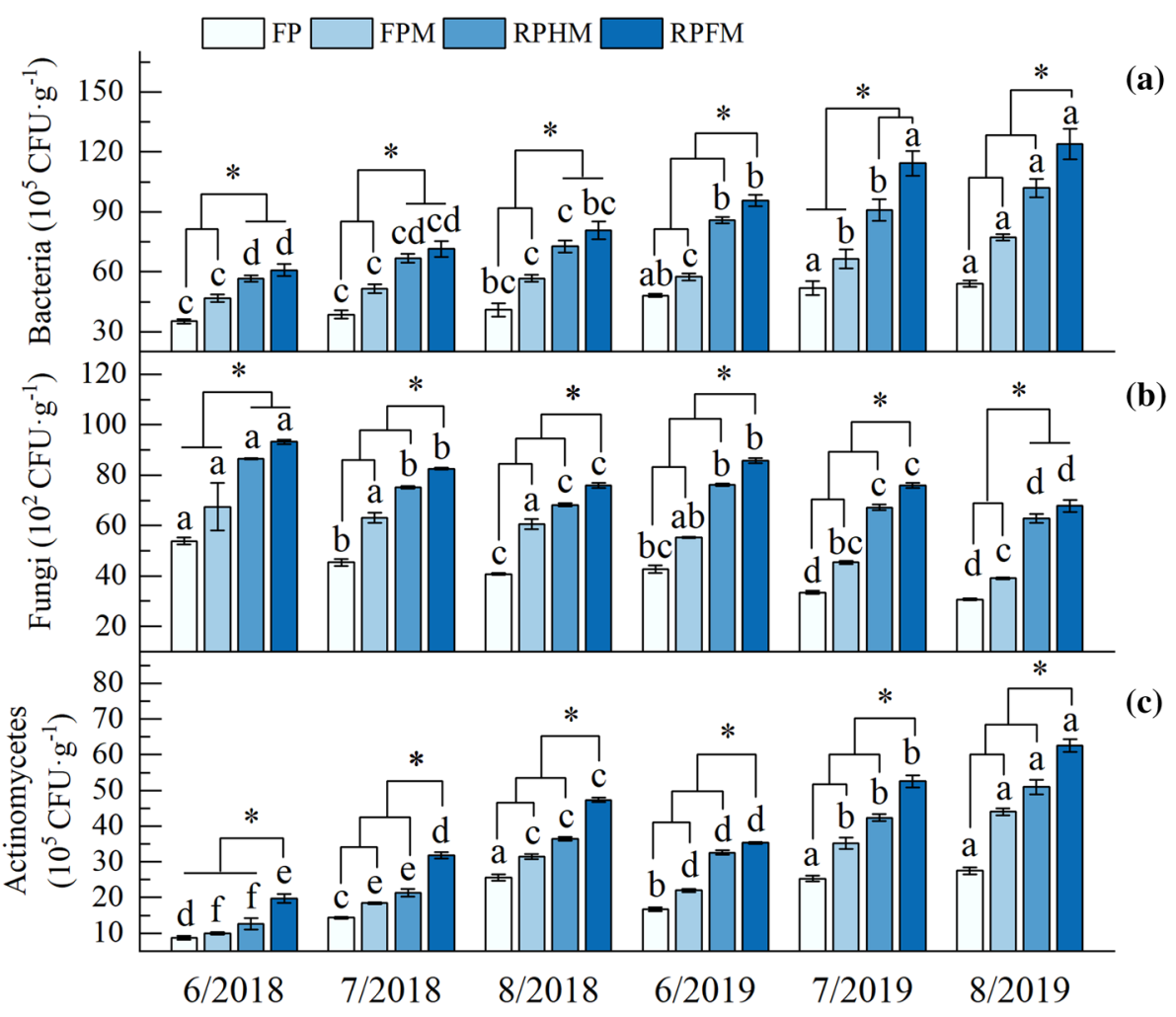

Fig. 5 Effects of plastic film mulching treatments for potato on a soil bacteria, $\mathbf{b}$ fungi, and $\mathbf{c}$ actinomycetes. Different lowercase letters indicate significant differences for the same treatment on different sample dates $(P<0.05)$, and asterisks indicate significant differences among treatments on the same sample date $(P<0.05)$. FP, flat plot without film mulching; FPM, flat plot with film mulching; RPHM, ridge planting with half mulch; RPFM, ridge planting with full mulch

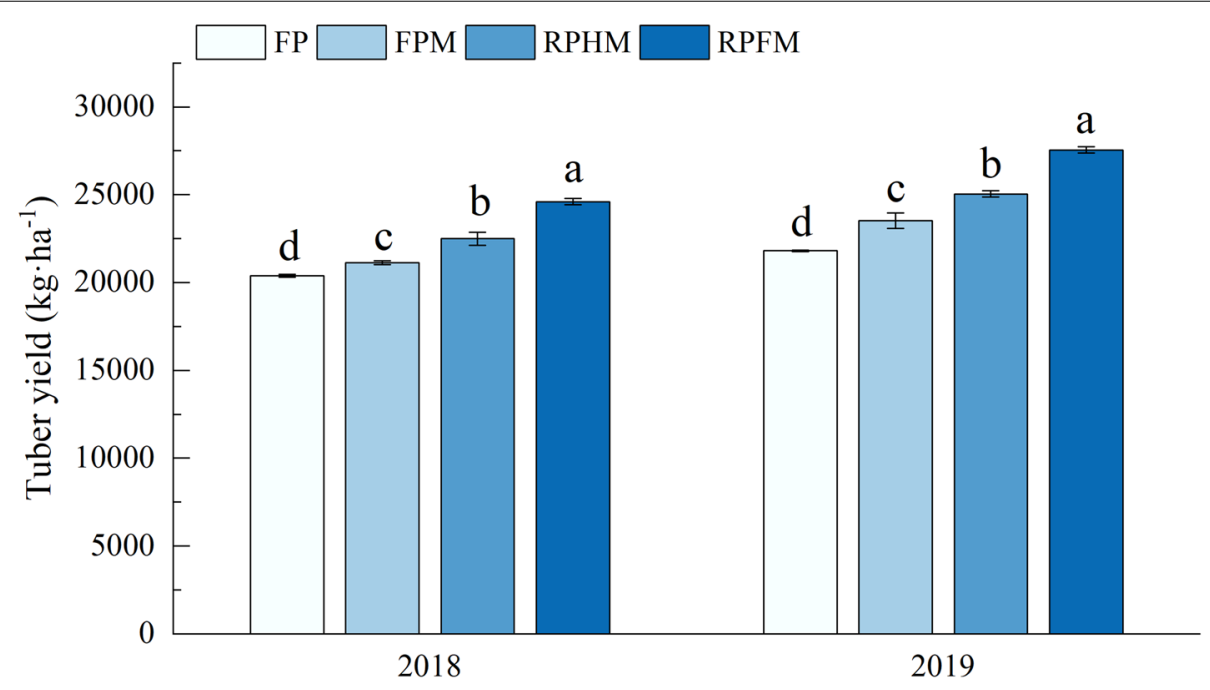

Fig. 6 Effects of plastic film mulching treatments for potato on tuber yield. Different lowercase letters indicate significant differences among treatments within a year $(P<0.05)$. FP, flat plot without film mulching; FPM, flat plot with film mulching; RPHM, ridge planting with half mulch; RPFM, ridge planting with full mulch 
Table 1 Potato yield by three classes of tuber weight under different plastic film mulching treatments

\begin{tabular}{|c|c|c|c|c|c|c|}
\hline \multirow[t]{3}{*}{ Treatment } & \multicolumn{6}{|l|}{ Weight (\%) } \\
\hline & \multicolumn{3}{|l|}{2018} & \multicolumn{3}{|l|}{2019} \\
\hline & Large potatoes (\%) & $\begin{array}{l}\text { Medium potatoes } \\
(\%)\end{array}$ & Small potatoes (\%) & Large potatoes (\%) & $\begin{array}{l}\text { Medium potatoes } \\
\text { (\%) }\end{array}$ & Small potatoes (\%) \\
\hline FP & $12.07 \pm 0.52 d$ & $59.69 \pm 0.37 b$ & $28.24 \pm 0.24 a$ & $12.51 \pm 0.37 d$ & $61.53 \pm 0.46 a$ & $25.95 \pm 0.24 a$ \\
\hline FPM & $15.56 \pm 0.11 c$ & $62.85 \pm 0.62 a$ & $21.58 \pm 0.65 b$ & $16.83 \pm 0.25 c$ & $62.63 \pm 0.40 \mathrm{a}$ & $20.54 \pm 0.28 b$ \\
\hline RPHM & $17.90 \pm 0.40 b$ & $62.91 \pm 0.33 a$ & $19.19 \pm 0.72 c$ & $19.84 \pm 0.40 b$ & $62.02 \pm 0.64 a$ & $18.15 \pm 0.26 c$ \\
\hline RPFM & $20.21 \pm 0.24 a$ & $62.01 \pm 0.46 a$ & $17.79 \pm 0.22 d$ & $21.61 \pm 0.09 a$ & $61.68 \pm 0.10 a$ & $16.71 \pm 0.03 c$ \\
\hline
\end{tabular}

Data are mean \pm standard error of the three replicates. Different lowercase letters in the same column indicate significant differences among treatments $(P<0.05)$ FP, flat plot without film mulching; FPM, flat plot with film mulching; RPHM, ridge planting with half mulch; RPFM, ridge planting with full mulch

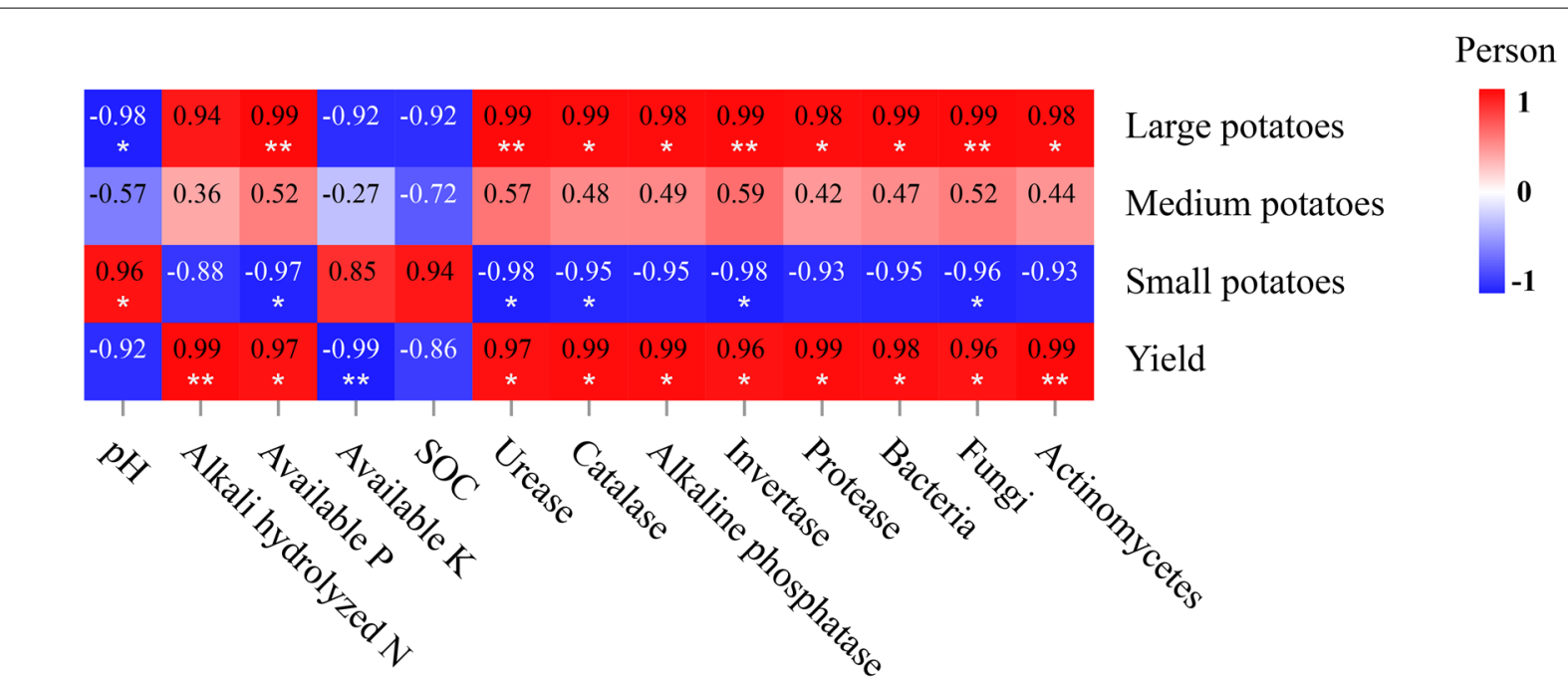

Fig. 7 Pearson coefficients of correlation between potato yield and tuber size classes and soil nutrients, enzyme activities, and microbial groups across plastic film treatments. ${ }^{*} P<0.05$ and ${ }^{* *} P<0.01$

alkali-hydrolyzed $\mathrm{N}$ and numbers of actinomycetes were highly significantly positively correlated with yield.

Available P content, urease, sucrase activities, and fungal numbers were highly significantly positively correlated with large potatoes, whereas catalase, alkaline phosphatase, and protease activities, and bacterial and actinomycete numbers were significantly positively correlated with large potatoes (Fig. 7). Small potatoes were negatively correlated with available $\mathrm{P}$ content, urease, catalase, and sucrase activities, and fungal numbers but positively correlated with $\mathrm{pH}$ (Fig. 7).

\section{Discussion}

\section{Effects of film mulching on soil chemical properties}

Soils are the primary source of nutrients absorbed by crops, and soil nutrient content determines whether plants can successfully grow and develop [31, 32]. Soil
$\mathrm{pH}$ and available nutrients are important indicators of changes in soil fertility, which can directly affect crop growth in a growing season [12]. In our study, compared with 2018, $\mathrm{pH}$, alkali-hydrolyzed $\mathrm{N}$, available $\mathrm{P}$, and available $\mathrm{K}$ in 2019 , increased in the different treatments. These results are consistent with those of previous studies $[2,19]$ and indicate that reasonable plastic film mulching can improve soil nutrient contents. As we all know, plastic mulching increases soil moisture and temperature, further changing the chemical properties of soil $[2,9]$. During the growing season, soil $\mathrm{pH}$ and available $\mathrm{P}$ content in different treatments first increased and then decreased. Among treatments, the highest $\mathrm{pH}$ was in FP, whereas available P in RPFM was higher than that in FP. Plastic film mulching promotes the respiration of roots and soil microorganisms, accelerates the decomposition of organic matter, and increases the concentration of carbon dioxide in soil $[17,32]$. Therefore, $\mathrm{pH}$ declined 
and available P content increased in RPFM. Alternating dry and wet soils after ridge sowing also affect nutrient contents [23], so that the content of alkali-hydrolyzed $\mathrm{N}$ in RPFM was significantly higher than that in other treatments. In addition, contents of alkali-hydrolyzed $\mathrm{N}$ and available $\mathrm{K}$ decreased during the growing season because of increased demand for $\mathrm{N}$ and $\mathrm{K}$ in the late stage of tuber growth [33, 34]. However, the change of soil SOC between different treatments was not significant. Yu et al. [35] found that long-term mulching had no significant effect on the content of SOC of wheat, corn, and oil crops, and even significantly reduced the SOC in rice soil. It can be seen that mulching can input more SOC by enhancing plant biomass, meanwhile, the mineralization rate of SOC also improves, and increasing the turnover rate of SOC; therefore, there was no significant increase in SOC. These results are consistent with the results of this study. Overall, soil $\mathrm{pH}, \mathrm{SOC}$, and alkali-hydrolyzed $\mathrm{N}$, available $\mathrm{P}$, and available $\mathrm{K}$ contents are influenced by plant species, soil type, fertilizer amount, and water content, and the different factors have different effects on soil nutrient availability.

\section{Effects of film mulching on soil enzyme activities}

Soil enzymes are essential biologically active substances involved in energy flow and material exchange in agroecosystems $[29,36]$. Film mulching can increase enzyme activity and provide favorable conditions for crop growth and development [4]. In this study, the increase in soil enzyme activity was an indication of potential improvement in soil quality. This was probably due to plastic film mulching changing the numbers of soil microorganisms, there are differences in soil microbial community catabolism, which in turn affect soil enzyme activities [21, 37, 38]. Soil urease activity in the different treatments first increased and then decreased during the growing season in 2019. Urease catalyzes urea hydrolysis in soil and has strong specificity [38]. Moreover, because urease is an important hydrolase in soil nitrogen cycling processes, it can reflect the $\mathrm{N}$-supplying ability of soil to a certain extent [39]. In contrast to urease, alkaline phosphatase activity first decreased and then increased. Ridge sowing also affects soil enzyme activities, because film mulching increases in soil water, and heat promote soil microbial activity $[2,14,40,41]$. We found that the activities of sucrase and protease increased slowly, and RPFM had the highest enzymatic activity. Soil sucrase activity is directly related to the number of soil microorganisms [41], and a similar result was observed in this study. Thus, plastic film mulching significantly increased soil enzyme activities in the potato field in this study. In concordance with that, semi-plastic film ridge sowing and full-plastic film ridge sowing had different effects on soil enzyme activities, supporting previous results that the type of mulching method can also affect soil enzyme activities [14].

\section{Effects of film mulching on soil microorganisms}

Microorganisms are essential in soil ecosystems because of their roles in material circulation and energy transformations and effects on plant growth [42]. In this research, the numbers of bacteria and actinomycetes in 2019 were higher than those in 2018, but the number of fungi declined slowly. Therefore, plastic film mulching changed soil microbial community structure, similar to the findings of Sreejata et al. [43]. Film mulching also increased the numbers of soil microorganisms in maize and wheat fields $[13,44]$. Results showed that the numbers of bacteria and actinomycetes in each treatment gradually increased over the growing season, whereas the numbers of fungi decreased. Plastic film mulching reduces soil water evaporation, improves soil temperature, promotes plant root secretions, and stimulates soil microbial growth and reproduction [45].

With plastic film mulching and ridge sowing, numbers of soil bacteria, fungi, and actinomycetes remained at high levels, because soil moisture and temperatures promoted microbial activities. Simultaneously, in the treatment without mulching, fungi increased, indicating the balance between rhizosphere microorganisms was destroyed [46]. Therefore, plastic film mulching and ridge cultivation changed the numbers of soil microorganisms in potato fields to achieve a balance between microbial populations and improve soil fertility.

\section{Effects of film mulching on potato yield}

Potato yields indicated that plastic film mulching significantly affected crop growth (Fig. 6). Tuber yield in 2019 increased by $7.0 \%$ to $11.9 \%$ compared with that in 2018 . Thus, plastic film mulching positively affected potato tuber yields. Mendonça et al. [21] found that plastic film mulching also increased tomato yields under field conditions.

Yields of plastic film mulching treatments (RPFM, RPHM, and FPM) were $3.7 \%$ to $26.4 \%$ higher than that of FP. The higher yields could be explained because plastic film mulching reduced soil water evaporation and ridge planting promoted the growth of soil microorganisms, both of which positively affected crop yields [40, 41, 45]. At the same time, mulching increased soil enzyme activity and changed the soil nutrient profile, thus promoted the growth of potato tubers $[2,15,18]$.

In 2019, the number of large potatoes in each treatment was higher than that in 2018, whereas the number of small potatoes was lower compared to 2018, indicating that plastic film mulching had a significant effect on 
the composition of potato yield [3]. In addition, the percentage of large potatoes in RPFM, RPHM, and FPM were significantly higher than that of FP in 2018 and 2019. Therefore, in addition to the positive effects of film mulching on potato yield [22], in this study, the percentage of large and medium potatoes increased significantly and that of small tubers decreased significantly in film mulching treatments. However, this study involved only one potato variety and future experiments should focus on the effects of ridge planting with full mulch on the yield and quality of multiple varieties.

\section{Conclusion}

RPFM caused the changes in the soil microbial population and soil enzyme activity and nutrients, which in turn contributed to increased tuber yield and growth of the potato. RPFM had the greatest positive effects on soil fertility and potato yield, and therefore, ridge planting with full mulch was recommended as an effective practice for potato cultivation in semiarid areas.

\section{Supplementary Information}

The online version contains supplementary material available at https://doi. org/10.1186/s40538-022-00284-5.

Additional file 1: Table S1. The F values of two-way ANOVAs for effects of the month, treatment, and their interactions on soil properties. Table S2. The $F$ values of two-way ANOVAs for effects of year, treatment, and their interactions on potato yield and yield composition.

\section{Acknowledgements}

We sincerely thank all the staff and students in the Dingxi Academy of Agricultural Sciences for their assistance with fieldwork.

\section{Authors' contributions}

Conceptualization, methodology, and writing —original draft, MS; data curation and writing - review and editing, WZ and SQ; software, YK, YF, XY, and $A G$; methodology, $X Y$, and $A G$; investigation, $H Y$; formal analysis, RZ; funding acquisition, SQ. All authors read and approved the final manuscript.

\section{Funding}

This research was supported by the National Natural Science Foundation of China (32060441), the Agriculture Research System of China (CARS-09-P14), the Outstanding Graduate Student Innovation Star Project in Gansu Province (2021CXZX-378), and the Discipline Construction Fund Project of Gansu Agricultural University (GAU-XKJS-2018-225).

\section{Availability of data and materials}

All data obtained from the current study are available from the corresponding author on a reasonable request.

\section{Declarations}

Ethics approval and consent to participate Not applicable.

\section{Consent for publication}

All co-authors have seen and agreed on the contents of the manuscript, and there is no financial interest to report.

\section{Competing interests}

The authors declare no conflict of interest.

\section{Author details}

${ }^{1}$ College of Horticulture, Gansu Agricultural University, Lanzhou 730070, China. ${ }^{2}$ Northwest Institute of Eco-Environment and Resources, Lanzhou 730000, China.

Received: 31 October 2021 Accepted: 10 January 2022

Published online: 21 January 2022

References

1. Chen YZ, Chai SX, Tian HH, Chai YW, Li YW, Chang L, Cheng HB. Straw strips mulch on furrows improves water use efficiency and yield of potato in a rainfed semiarid area. Agric Water Manag. 2019;211:142-51.

2. Qin SH, Zhang JL, Dai HL, Wang D, Li DM. Effect of ridge-furrow and plastic-mulching planting patterns on yield formation and water movement of potato in a semi-arid area. Agric Water Manag. 2014;131:87-94.

3. Qin SH, Yeboah S, Cao L, Zhang JL, Shi SL, Liu YH. Breaking continuous potato cropping with legumes improves soil microbial communities, enzyme activities and tuber yield. PLOS ONE. 2017;12(5):e0175934.

4. Qin SH, Cao L, Zhang JL, Wang D, Wang D. Soil nutrient availability and microbial properties of a potato field under ridge-furrow and plastic mulch. Arid Land Res Manage. 2016;30(2):181-92.

5. Kang YC, Zhang WN, Yang XY, Liu YH, Fan YL, Shi MF, Yao K, Qin SH. Furrow-ridge mulching managements affect the yield, tuber quality and storage of continuous cropping potatoes. Plant Soil Environ. 2020;66(11):576-83.

6. Wang Q, Zhang EH, Li FM, Li FR. Runoff efficiency and the technique of micro-water harvesting with ridges and furrows, for potato production in semi-arid areas. Water Resour Manage. 2008;22(10):1431-43.

7. Qin SH, Yeboah S, Xu XX, Liu YH, Yu B. Analysis on fungal diversity in rhizosphere soil of continuous cropping potato subjected to different furrow-ridge mulching managements. Front Microbiol. 2017;8:845.

8. Gattinger A, Ruser R, Schloter M, Munch JC. Microbial community structure varies in different soil zones of a potato field. J Plant Nutr Soil Sci. 2002;165(4):421-8.

9. Fan YL, Zhang WN, Kang YC, Zhao ZP, Yao K, Qin SH. Effects of ridge and furrow film mulching on soil environment and yield under potato continuous cropping system. Plant Soil Environ. 2019;65(11):523-9.

10. Gao ZY, Hu YY, Han MK, Xu JJ, Wang X, Liu LF, Tang ZH, Jiao WJ, Jin R, Liu M, Guan ZJ, Ma ZM. Effects of continuous cropping of sweet potatoes on the bacterial community structure in rhizospheric soil. BMC Microbiol. 2021;21(1):102-102

11. Alotaibi KD, Arcand M, Ziadi N. Effect of biochar addition on legacy phosphorus availability in long-term cultivated arid soil. Chem Biol Technol Agric. 2021;8(1):47.

12. Yu YC, Yang JY, Zeng SC, Wu DM, Jacobs DF, Sloan JL. Soil pH, organic matter, and nutrient content change with the continuous cropping of Cunninghamia lanceolata plantations in South China. J Soils Sediments. 2017;17(9):2230-8

13. Li YZ, Hu YC, Song DP, Liang SH, Siddique KHM. The effects of straw incorporation with plastic film mulch on soil properties and bacterial community structure on the loess plateau. Eur J Soil Sci. 2021;72(2):979-94.

14. Zhang XY, You SY, Tian YQ, Li JS. Comparison of plastic film, biodegradable paper and bio-based film mulching for summer tomato production: soil properties, plant growth, fruit yield and fruit quality. Sci Hortic. 2019;249:38-48.

15. Zhang XD, Yang LC, Xue XK, Kamran M, Ahmad I, Dong ZY, Liu TN, Jia ZK, Zhang P, Han QF. Plastic film mulching stimulates soil wet-dry alternation and stomatal behavior to improve maize yield and resource use efficiency in a semi-arid region. Field Crops Res. 2019;233:101-13.

16. Gu XB, Cai HJ, Du YD, Li YN. Effects of film mulching and nitrogen fertilization on rhizosphere soil environment, root growth and nutrient uptake of winter oilseed rape in northwest China. Soil Tillage Res. 2019;187:194-203.

17. Gu YJ, Han CL, Fan JW, Shi XP, Kong M, Shi XY, Siddique KHM, Zhao YY, Li FM. Alfalfa forage yield, soil water and $P$ availability in response to plastic 
film mulch and P fertilization in a semiarid environment. Field Crops Res. 2018;215:94-103.

18. Jia HC, Zhang Y, Tian SY, Emon RM, Yang XY, Yan HR, Wu TT, Lu WC, Siddique KHM, Han TF. Reserving winter snow for the relief of spring drought by film mulching in northeast China. Field Crops Res. 2017;209:58-64.

19. Zhou LM, Jin SL, Liu CA, Xiong YC, Si JT, Li XG, Gan YT, Li FM. Ridge-furrow and plastic-mulching tillage enhances maize-soil interactions: opportunities and challenges in a semiarid agroecosystem. Field Crops Res. 2012:126:181-8.

20. Alam SMK, Matin MA, Hossain MA, Uddin MK. Effect of different tillage systems on some physical and chemical properties of a silt loam soil in rice field. J Biol Sci. 2002;2(8):524-7.

21. Mendonça SR, Ávila MCR, Vital RG, Evangelista ZR, Pontes NDC, Nascimento ADR. The effect of different mulching on tomato development and yield. Sci Hortic. 2021;275:109657.

22. Li Q, Li HB, Zhang L, Zhang SQ, Chen YL. Mulching improves yield and water-use efficiency of potato cropping in China: a meta-analysis. Field Crops Res. 2018:221:50-60.

23. Zhang XD, Zhao J, Yang LC, Kamran M, Xue XK, Dong ZY, Jia ZK, Han QF. Ridge-furrow mulching system regulates diurnal temperature amplitude and wetting-drying alternation behavior in soil to promote maize growth and water use in a semiarid region. Field Crops Res. 2019;233:121-30.

24. Crossman S, Joyner M, Lugolópez A. FAO yearbook: fertilizer. 1990.

25. Zhang W, Zhao J, Pan FJ, Li DJ, Chen HS, Wang KL. Changes in nitrogen and phosphorus limitation during secondary succession in a karst region in southwest China. Plant Soil. 2015;391(1-2):77-91.

26. Kayikcioglu HH, Duman I, Asciogul TK, Bozokalfa MK, Elmaci OL. Effects of tomato-based rotations with diversified pre-planting on soil health in the Mediterranean soils of Western Turkey. Agric Ecosyst Environ. 2020;299:106986

27. Mebius $L J$. A rapid method for the determination of organic carbon in soil. Anal Chim Acta. 1960;22(1):120-4.

28. Black CA. Method of soil analysis part 2. Chemical \& microbiological properties. Madison: American Society of Agronomy, Inc.; 1965.

29. Kucharski J, Tomkiel M, Bacmaga M, Borowik A, Wyszkowska J. Enzyme activity and microorganisms diversity in soil contaminated with the Boreal 58 WG herbicide. J Environ Sci Health B. 2016:51(7):446-54.

30. Watanabe K, Hayano K. Seasonal variation of soil protease activities and their relation to proteolytic bacteria and Bacillus spp. in paddy field soil. Soil Biol Biochem. 1995;27(2):197-203.

31. Fu ZD, Zhou L, Chen P, Du Q, Pang T, Song C, Wang XC, Liu WG, Yang WY Yong TW. Effects of maize-soybean relay intercropping on crop nutrient uptake and soil bacterial community. J Integr Agric. 2019;18(9):2006-18.

32. Zhang $L C$, Li J, Zhang MQ. Effect of rice-rice-rape rotation on physicochemical property and bacterial community of rhizosphere soil. Oil Crop Sci. 2020;5(3):149-55.

33. Koch M, Naumann M, Pawelzik E, Gransee A, Thiel H. The importance of nutrient management for potato production part I: plant nutrition and yield. Potato Res. 2020;63(1):97-119.

34. Dong HD, Liu T, Han ZQ, Sun QM, Li R. Determining time limits of continuous film mulching and examining residual effects on cotton yield and soil properties. J Environ Biol. 2015;36(3):677-84.

35. Yu YX, Zhang YX, Xiao M, Zhao CY, Yao HY. A meta-analysis of film mulching cultivation effects on soil organic carbon and soil greenhouse gas fluxes. CATENA. 2021;206(2):105483.

36. Innangi M, Niro E, D'ascoli R, Danise T, Proietti P, Nasini L, Regni L, Castaldi S, Fioretto A. Effects of olive pomace amendment on soil enzyme activities. Appl Soil Ecol. 2017:119:242-9.

37. Wang LL, Coulter JA, Li LL, Luo ZZ, Chen YL, Deng XP, Xie JH. Plastic mulching reduces nitrogen footprint of food crops in China: a metaanalysis. Sci Total Environ. 2020;748:141479.

38. Zhang YL, Wang FX, Shock CC, Feng SY. Modeling the interaction of plastic film mulch and potato canopy growth with soil heat transport in a semiarid area. Agronomy. 2020;10(2):190.

39. Chang EH, Chung RS, Tsai YH. Effect of different application rates of organic fertilizer on soil enzyme activity and microbial population. Soil Sci Plant Nutr. 2010;53(2):132-40.

40. Qin $\mathrm{SH}$, Yeboah $\mathrm{S}$, Wang $\mathrm{D}$, Zhang JL. Effects of ridge-furrow and plastic mulching planting patterns on microflora and potato tuber yield in continuous cropping soil. Soil Use Manag. 2016:32(3):465-73.
41. Wang JW, Niu WQ, Dyck M, Zhang MZ, Li Y. Drip irrigation with film covering improves soil enzymes and muskmelon growth in the greenhouse. Soil Res. 2018;56(1):59-70

42. Aschi A, Aubert M, Riah-Anglet W, Nelieu S, Dubois C, Akpa-Vinceslas $M$, Trinsoutrot-Gattin I. Introduction of Faba bean in crop rotation: impacts on soil chemical and biological characteristics. Appl Soil Ecol. 2017:120:219-28.

43. Bandopadhyay S, Martin-Closas L, Pelacho AM, DeBruyn JM. Biodegradable plastic mulch films: impacts on soil microbial communities and ecosystem functions. Front Microbiol. 2018;9:819.

44. Qi YL, Ossowicki A, Yang XM, Lwanga EH, Dini-Andreote F, Geissen V, Garbeva P. Effects of plastic mulch film residues on wheat rhizosphere and soil properties. J Hazard Mater. 2020;387:121711.

45. Li XY, Simunek J, Shi HB, Yan JW, Peng ZY, Gong XW. Spatial distribution of soil water, soil temperature, and plant roots in a drip-irrigated intercropping field with plastic mulch. Eur J Agron. 2017:83:47-56.

46. Ma K, Zhang L, Du Q, Song NP. Effect of potato continuous cropping on soil microorganism community structure and function. J Soil Water Conserv. 2010;24(4):229-33.

\section{Publisher's Note}

Springer Nature remains neutral with regard to jurisdictional claims in published maps and institutional affiliations.

\section{Submit your manuscript to a SpringerOpen ${ }^{\circ}$ journal and benefit from:}

- Convenient online submission

- Rigorous peer review

- Open access: articles freely available online

- High visibility within the field

- Retaining the copyright to your article

Submit your next manuscript at $\boldsymbol{\nabla}$ springeropen.com 